BIOMEDICAL AND BIOSOCIAL ANTHROPOLOGY
$\begin{gathered}\text { Official Journal of the International Academy } \\ \text { of Integrative Anthropology } \\ \text { journal homepage: http://bba-journal.com }\end{gathered}$

\title{
Features of quantitative indicators of finger and palmar dermatoglyphics in males and females with ichthyosis
}

Dmytrenko S. V. ${ }^{1}$, Klimas L. A. ${ }^{1}$, Kushnir V. A. ${ }^{2}$, Serebrennikova O. A. ${ }^{1}$, Serheta I.V. ${ }^{1}$

${ }^{1}$ National Pirogov Memorial Medical University, Vinnytsya, Ukraine

${ }^{2}$ Military Medical Clinical Center of the Central Region, Vinnytsya, Ukraine

\section{ARTICLE INFO}

Received: 4 July, 2018

Accepted: 23 August, 2018

UDC: $616.5-003.871-055.2 /$

$.1: 572.524 .12$

\section{CORRESPONDING AUTHOR}

e-mail: svetlana7783@ukr.net

Dmytrenko S. V.
Heterogeneity by types of genodermatoses inheritance from the group of ichthyosis, which include virtually all possible variants, is the basis for the application of one of the genetic methods of human study - the method of dermatoglyphics. The purpose of the study is to determine the peculiarities of the quantitative indexes of finger and palmar dermatoglyphics in men and women with ichthyosis. Dermatological examination was performed in 49 patients with ichthyosis and 136 dermatologically healthy persons. The sample of patients was conducted randomly. All persons received informed consent for conducting observations. Fingerprint and palm prints are obtained by scanning fingerprints on paper by the Futronic's FS8 USB2.0 Fingerprint Scanner using the ftrScanApiEx.exe program, and then transferring data to a personal computer. Processing of dermatoglyphics data was carried out according to the method of Cummins $\mathrm{H}$. and Midlo Ch. (1961). The quantitative indices of both finger and palmar dermatoglifics were determined. The calculation of the received results was carried out in the licensed software package "Statistica 5.5". The average sample values $(M)$ and dispersion $(\sigma)$ were determined in the groups of the subjects surveyed. Using the Mann-Whitney U-test determined the probability of differences in the results obtained for individual groups. A certain complex of quantitative signs of palmar dermatoglyphics is revealed, which is characteristic for men suffering from ichthyosis, which includes indexes of the intensity of the comb formations, the value of the length of the segment $c-t$, the value of the palm corners and the Cummins index. In women suffering from ichthyosis, such a complex includes, as in men, indicators of the intensity of the combs and the length of the segment c-t, except for which - also the value of palm comb accounts. Given the specific lamellar form of ichthyosis, the dermatoglyphic picture (monomorphism of established signs on both hands: the presence of a single 4-finger flexural fold, a pattern in the III interdigital gap, low localization of the carpal angle atd, and the presence of the ulnar loop, complicated by the internal pattern on the III finger of the left and the IV the finger of the right hand brushes), the authors concluded that the study of ichthyosis should be carried out necessarily for each form of ichthyosis separately, which significantly increases the resolution of the method of dermatoglyphics.

Keywords: ichthyosis, lamellar ichthyosis, dermatoglyphics, men, women.

\section{Introduction}

At the heart of the scientific interest of geneticists, clinicians and anthropologists in dermatoglyphics is the understanding of the high hereditary condition of the skin pattern and the possibility of using it as a marker of hereditary diseases [28, 31, 32, 33], and the morphogenetic marker [1, 9, 16, 20, 21, 22, 33]. Recently, interest in dermatoglyphics is due to the emergence of new powerful methods of mathematical analysis and the discovery of new facets of the use of dermatoglyphics in medicine.
Numerous publications appeared, the results of which formed the understanding of the association of signs of dermatoglyphics with a number of diseases of multifactorial nature $[8,10-14,17,24,26,29,30]$, where dermatoglyphics plays, as a rule, a prognostic role.

Ichthyosis encompasses a heterogeneous group of hereditary skin diseases that can be congenital or develop in childhood [5]. Given that genodermatosis from the group of ichthyosis are heterogeneous by types of inheritance 
and include virtually all possible variants: dominant, recessive, linked to the $X$ chromosome, autosomal [19, 23], and the congenital autosomal recessive ichthyosis is genetically highly heterogeneous and is associated with 6 genes: TGM1, ALOXE3, ALOX12B, NIPAL4, CYP4F22 and $A B C A 12$ [27], the use of the dermatologic method in the study of ichthyosis of various forms will create additional possibilities for their diagnostic differentiation and prediction of the course of this disease.

The purpose of the study is to determine the peculiarities of the quantitative indexes of finger and palmar dermatoglyphics in men and women with ichthyosis.

\section{Materials and methods}

This cohort examination was conducted during 5 years in a population of 70 patients with ichthyosis, who were at the dispensary supervision and treatment (outpatient and/ or inpatient). In 49 patients with ichthyosis, dermatoglyphic examination was performed. All patients were under the dispensary supervision and treatment at the dermatologist at their place of residence, received treatment in accordance with the protocols for the provision of medical care to the population approved by the Ministry of Health of Ukraine (http:/ /www.moz.gov.ua/ua/portal/dn_20090508_312.html). The examination of the patients of the experimental group was carried out at the place of residence and at the visit to the Vinnytsia Regional Skin and Venereal Dispensary.

To identify clinical and laboratory features, a special questionnaire was developed, which took into account the main clinical and laboratory indicators in accordance with national and international recommendations for the management of patients with ichthyosis. The survey methodology was developed in accordance with the requirements of modern clinical epidemiology. The questionnaires were checked directly after the interview in order to identify missing information or inconsistencies in the data. The completed questionnaires were subject to thorough analysis and supplemented by information from the primary documentation of the patient's medical records or outpatient card. Gathered data on the genealogical status, peculiarities of gynecological status of a woman, nature of the course of pregnancy, childbirth and type of feeding. Related pathologies were determined. From the medical records received data on the number and nature of hospitalizations, the features of treatment, its duration. Separately there were recorded data of physical examination and results of standard and auxiliary methods of research that included blood and urine tests, blood biochemical parameters, x-ray of the chest organs, electrocardiography, and standard bacteriological studies. Registered consultations of doctors-specialists in related specialties. A comparison group was a group of 136 dermatologically healthy individuals who performed a similar questionnaire and survey.

All patients who participated in the study received informed consent for follow-up, which was approved by the

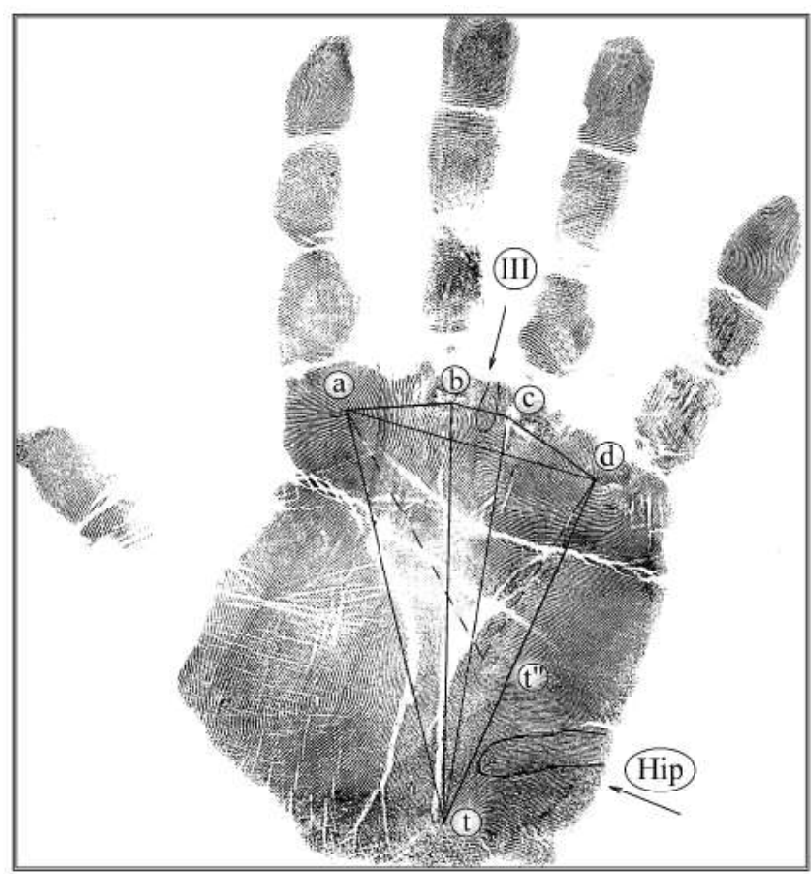

Fig. 1. Definition of palm angels: the simultaneous presence of two axial triradiuses: carpal $\mathrm{t}(\angle \mathrm{atd}=37$ ) and intermediate $\mathrm{t}$ ( $\angle \mathrm{at}$ 'd $=60$ ), counting the number of combs crossing the intervals between the palm triadiuses a-b, b-c, c-d (taken from [15]).

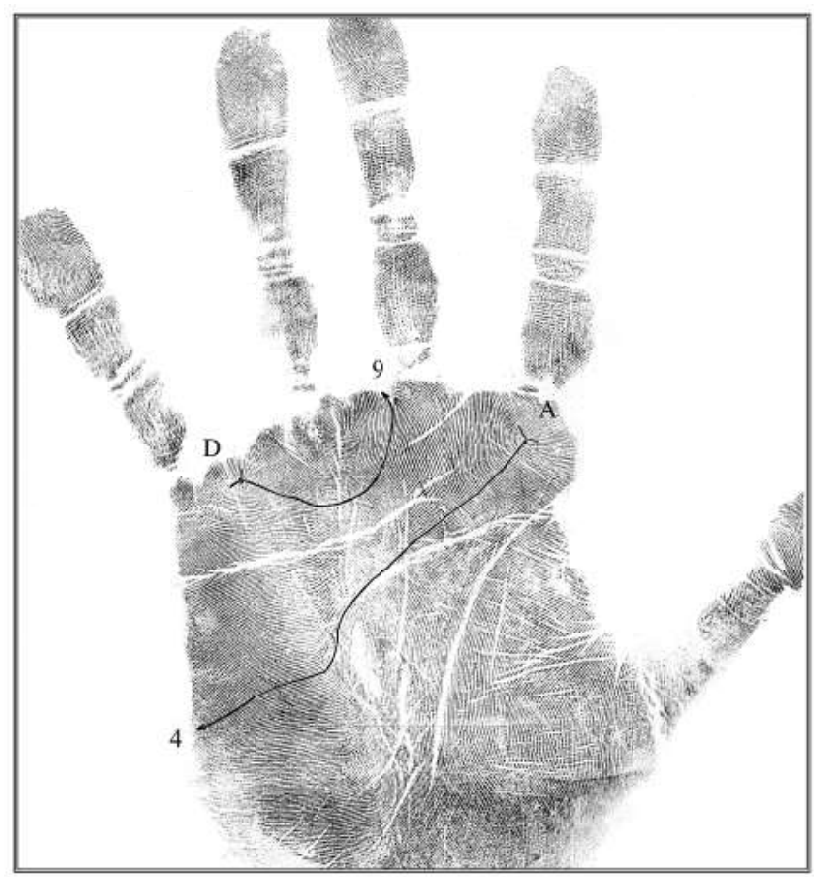

Fig. 2. Example of pace and determining the field of main end palmar lines (taken from [15]).

decision of the Bioethics and Ethics Commission of National Pirogov Memorial Medical University, Vinnytsya (protocol No. 5 dated 04.09.2015).

Fingerprint and palm prints are obtained by scanning fingerprints on paper by the Futronic's FS8 USB2.0 Fingerprint Scanner using the ftrScanApiEx.exe program, 
and then transferring data to a personal computer. Processing was carried out according to the method of Cummins $\mathrm{H}$. and Midlo Ch. [3]. The quantitative indices were determined as for finger (comb account of each finger individually, a total comb count for 5 fingers of each hand separately and a total comb for 10 fingers), and palmar dermatoglyphics (length of segments a-d and c-t, connecting the corresponding triradius, palmar sizes of angles atd, atb, btc, ctd, dat, palm comb accounts a-b, b-c, c-d, finish of the main palm lines $A$ and $D$ (Fig. 1, Fig. 2).

The calculations were carried out on a personal computer in the software package "Statistica 5.5" (owned by CSIT National Pirogov Memorial Medical University, Vinnytsya, licensed number AXXR910A374605FA). The results of the study were processed with the calculation of the mean sample values (M) and dispersion $(\sigma)$ in the groups of examined individuals. Using Mann-Whitney U-test determined the probability of differences in the results obtained for individual groups.

\section{Results}

The results of the study of the main quantitative indexes of finger and palmar dermatoglyphics, which were carried out separately for the left and right hands, as well as for both hands, showed the presence of certain features of dermatoglyphics in men and women with ichthyosis (Table 1-3).

Men suffering from ichthyosis have a significantly lower finger comb score of I (17.41 \pm 5.72 vs. $19.94 \pm 6.16$ comb, $p<0.05)$ and $V(11.19 \pm 5.29$ vs. $13.49 \pm 5.19$ comb, $p<0.05)$ fingers of the right hand compared to practically healthy men (see Table 1). In women with ichthyosis, according to the indicated indicators statistically significant differences from healthy individuals were not detected (see Table 1).

It was found that in women with ichthyosis, the finger comb score of the right IV hand finger was significantly lower (13.03 \pm 6.35 versus $14.84 \pm 4.96$ comb, $p<0.05$ ), compared with practically healthy women (see Table 1). In men with ichthyosis, according to the indicated indicator, no statistically significant differences from healthy individuals were detected (see Table 1).

In men with ichthyosis, significantly higher values of the angles ctd on the right $\left(16.77 \pm 4.33^{\circ}\right.$ against $15.62 \pm 3.19^{\circ}$, $\mathrm{p}<0.05)$ and left $\left(16.32 \pm 5.12^{\circ}\right.$ against $15.42 \pm 3,12^{\circ}$, $\mathrm{p}<0.05)$ hands and the ats angel at the left hand (18.26 \pm $4.19^{\circ}$ against $16.79 \pm 3.11^{\circ}, \mathrm{p}<0.05$ ) compared with practically healthy men. There was no difference between the sick and healthy women according to these indicators (see Table 2).

Men also have a significantly lower length of the segment connecting palm triradius $\mathrm{c}$ and $\mathrm{t}$ on the right $(68.51 \pm$ $6.31 \mathrm{~mm}$ vs. $82.47 \pm 11.44 \mathrm{~mm}, \mathrm{p}<0.05)$ and left $(75.81 \pm$ $4.72 \mathrm{~mm}$ versus $83.50 \pm 11.19 \mathrm{~mm}, \mathrm{p}<0.05$ ) hands, compared with practically healthy men. Similarly, in female patients, the length of the segment c-t on the right $(68.76 \pm$ $7.39 \mathrm{~mm}$ against $73.57 \pm 9.83 \mathrm{~mm}, \mathrm{p}<0.05)$ and left $(68.51$ $\pm 4.38 \mathrm{~mm}$ versus $73.42 \pm 10.63 \mathrm{~mm}, \mathrm{p}<0.05$ ) hands is
Table 1. Quantitative indexes of digital dermatoglyphics in men and women with ichthyosis (absolute units) $(\mathrm{M} \pm \sigma)$.

\begin{tabular}{|c|c|c|c|c|}
\hline Indicator & Sex & $\begin{array}{c}\text { Practically } \\
\text { healthy }(n=58 \text { in } \\
\text { men) }(n=78 \text { in } \\
\text { women })\end{array}$ & $\begin{array}{c}\text { Patients with } \\
\text { ichthyosis }(n=24 \\
\text { in men) }(n=25 \text { in } \\
\text { women })\end{array}$ & $p$ \\
\hline \multirow{2}{*}{ FRC-RI } & M & $19.94 \pm 6.16$ & $17.41 \pm 5.72$ & $<0.05$ \\
\hline & W & $16.53 \pm 4.83$ & $16.91 \pm 5.89$ & $>0.05$ \\
\hline \multirow{2}{*}{ FRC-RII } & M & $11.64 \pm 7.56$ & $10.71 \pm 7.15$ & $>0.05$ \\
\hline & W & $10.85 \pm 7.12$ & $12.24 \pm 6.65$ & $>0.05$ \\
\hline \multirow{2}{*}{ FRC-RIII } & M & $12.50 \pm 5.57$ & $12.06 \pm 5.89$ & $>0.05$ \\
\hline & W & $11.57 \pm 6.21$ & $10.02 \pm 6.47$ & $>0.05$ \\
\hline \multirow{2}{*}{ FRC-RIV } & M & $16.38 \pm 5.26$ & $14.75 \pm 5.45$ & $>0.05$ \\
\hline & W & $14.84 \pm 4.96$ & $13.03 \pm 6.35$ & $<0.05$ \\
\hline \multirow{2}{*}{ FRC-RV } & $M$ & $13.49 \pm 5.19$ & $11.19 \pm 5.29$ & $<0.05$ \\
\hline & W & $11.72 \pm 5.00$ & $11.77 \pm 5.38$ & $>0.05$ \\
\hline \multirow{2}{*}{ FRC-R } & $\mathrm{M}$ & $73.94 \pm 23.06$ & $65.04 \pm 15.86$ & $>0.05$ \\
\hline & W & $65.52 \pm 21.62$ & $65.30 \pm 13.53$ & $>0.05$ \\
\hline \multirow{2}{*}{ FRC-LI } & M & $17.95 \pm 6.89$ & $13.31 \pm 6.68$ & $>0.05$ \\
\hline & W & $14.97 \pm 6.31$ & $13.36 \pm 6.97$ & $>0.05$ \\
\hline \multirow{2}{*}{ FRC-LII } & M & $10.86 \pm 6.66$ & $10.83 \pm 7.04$ & $>0.05$ \\
\hline & W & $11.52 \pm 6.82$ & $12.47 \pm 7.19$ & $>0.05$ \\
\hline \multirow{2}{*}{ FRC-LIII } & $M$ & $12.33 \pm 5.85$ & $11.40 \pm 6.07$ & $>0.05$ \\
\hline & W & $11.37 \pm 6.48$ & $11.61 \pm 6.02$ & $>0.05$ \\
\hline \multirow{2}{*}{ FRC-LIV } & M & $15.71 \pm 5.09$ & $15.59 \pm 4.50$ & $>0.05$ \\
\hline & $w$ & $14.69 \pm 5.71$ & $14.34 \pm 6.20$ & $>0.05$ \\
\hline \multirow{2}{*}{ FRC-LV } & $M$ & $13.31 \pm 5.46$ & $11.73 \pm 4.55$ & $>0.05$ \\
\hline & W & $12.26 \pm 5.26$ & $13.09 \pm 4.32$ & $>0.05$ \\
\hline \multirow{2}{*}{ FRC-L } & M & $70.19 \pm 23.43$ & $60.71 \pm 19.28$ & $>0.05$ \\
\hline & W & $65.10 \pm 23.51$ & $65.18 \pm 13.98$ & $>0.05$ \\
\hline \multirow{2}{*}{ TRC } & M & $143.1 \pm 44.7$ & $134.5 \pm 25.3$ & $>0.05$ \\
\hline & W & $130.8 \pm 44.0$ & $124.9 \pm 31.0$ & $>0.05$ \\
\hline
\end{tabular}

Notes: here and thereafter M - men; W - women; $p$ - statistical significance of differences between healthy and sick; $R$ - right hand; L - left hand; FRC - finger comb account; I, II, III, IV, V -number of the finger; SRC - total comb count for 5 fingers of hand; TRC total comb count for both hands.

significantly lower in comparison with practically healthy women (see Table 2).

In male patients, the value of the Cummins index of the right $(7.751 \pm 3.224$ versus $9.642 \pm 1.841, p<0.05)$ hand is significantly lower than that of practically healthy men. There was no difference between the sick and healthy women according to these indicators (see Table 3).

It was established that in female patients, the comb score between the palmar triradius $a$ and $b$ on the right (36.03 \pm 6.35 comb against $39.35 \pm 4.89 \mathrm{comb}, \mathrm{p}<0.05$ ) and the left $(37.79 \pm 6.11$ comb against $40.46 \pm 6.05$ comb, $p<0,05)$ hands and also - $b-c$ on the right $(24.24 \pm 5.96$ comb against $27.17 \pm 5.68 \mathrm{comb}, \mathrm{p}<0.05)$ and $\mathrm{c}$-d on the left $(34.58 \pm 6.97$ comb against $35.63 \pm 7.62$ comb, $p<0.05)$ hand are 
Table 2. Quantitative indices of palmar dermatoglyphics in men and women with ichthyosis (the values of the angles and lengths of the segments) $(\mathrm{M} \pm \sigma)$.

\begin{tabular}{|c|c|c|c|c|}
\hline Indicator & Sex & $\begin{array}{c}\text { Practically } \\
\text { healthy ( } n=58 \text { in } \\
\text { men) }(n=78 \text { in } \\
\text { women) }\end{array}$ & $\begin{array}{c}\text { Patients with } \\
\text { ichthyosis }(n=24 \\
\text { in men) }(n=25 \text { in } \\
\text { women) }\end{array}$ & $p$ \\
\hline \multirow{2}{*}{$\mathrm{R}-\mathrm{ATD}\left({ }^{\circ}\right)$} & M & $41.91 \pm 5.81$ & $41.46 \pm 5.56$ & $>0.05$ \\
\hline & W & $42.68 \pm 6.01$ & $42.21 \pm 6.24$ & $>0.05$ \\
\hline \multirow{2}{*}{$\mathrm{L}-\mathrm{ATD}\left({ }^{\circ}\right)$} & $M$ & $41.77 \pm 6.82$ & $41.13 \pm 7.45$ & $>0.05$ \\
\hline & W & $42.81 \pm 6.63$ & $42.87 \pm 5.44$ & $>0.05$ \\
\hline \multirow{2}{*}{$\mathrm{R}-\mathrm{CTD}\left({ }^{\circ}\right)$} & $M$ & $15.62 \pm 3.19$ & $16.77 \pm 4.33$ & $<0.05$ \\
\hline & W & $15.83 \pm 3.62$ & $16.85 \pm 4.24$ & $>0.05$ \\
\hline \multirow{2}{*}{$\mathrm{L}-\mathrm{CTD}\left({ }^{\circ}\right)$} & $M$ & $15.42 \pm 3.12$ & $16.32 \pm 5.12$ & $<0.05$ \\
\hline & $w$ & $15.63 \pm 3.24$ & $16.78 \pm 5.62$ & $>0.05$ \\
\hline \multirow{2}{*}{$\mathrm{R}-\mathrm{ATB}\left({ }^{\circ}\right)$} & $M$ & $16.26 \pm 2.71$ & $16.62 \pm 5.72$ & $>0.05$ \\
\hline & $w$ & $16.54 \pm 2.66$ & $17.27 \pm 4.82$ & $>0.05$ \\
\hline \multirow{2}{*}{$\mathrm{L}-\mathrm{ATB}\left({ }^{\circ}\right)$} & $M$ & $16.79 \pm 3.11$ & $18.26 \pm 4.19$ & $<0.05$ \\
\hline & $w$ & $16.95 \pm 3.22$ & $18.49 \pm 4.26$ & $>0.05$ \\
\hline \multirow{2}{*}{$\mathrm{R}-\mathrm{BTC}\left({ }^{\circ}\right)$} & $M$ & $10.48 \pm 2.99$ & $11.11 \pm 4.25$ & $>0.05$ \\
\hline & $w$ & $10.52 \pm 2.67$ & $11.43 \pm 4.55$ & $>0.05$ \\
\hline \multirow{2}{*}{ L - BTC $\left({ }^{\circ}\right)$} & $M$ & $10.09 \pm 2.87$ & $10.17 \pm 2.43$ & $>0.05$ \\
\hline & $w$ & $10.44 \pm 2.89$ & $10.43 \pm 2.38$ & $>0.05$ \\
\hline \multirow{2}{*}{$\mathrm{R}-\mathrm{DAT}\left({ }^{\circ}\right)$} & $M$ & $58.57 \pm 5.04$ & $58.51 \pm 6.11$ & $>0.05$ \\
\hline & $w$ & $57.36 \pm 4.85$ & $57.93 \pm 6.25$ & $>0.05$ \\
\hline \multirow{2}{*}{ L - DAT $\left({ }^{\circ}\right)$} & $M$ & $58.37 \pm 4.73$ & $57.29 \pm 4.18$ & $>0.05$ \\
\hline & $w$ & $57.47 \pm 3.46$ & $59.12 \pm 5.85$ & $>0.05$ \\
\hline \multirow{2}{*}{$\mathrm{R}-\mathrm{AD}(\mathrm{mm})$} & $M$ & $57.90 \pm 3.86$ & $57.12 \pm 4.26$ & $>0.05$ \\
\hline & $w$ & $47.80 \pm 3.88$ & $48.02 \pm 4.34$ & $>0.05$ \\
\hline \multirow{2}{*}{$\mathrm{L}-\mathrm{AD}(\mathrm{mm})$} & $M$ & $57.53 \pm 3.99$ & $57.65 \pm 5.29$ & $>0.05$ \\
\hline & $w$ & $46.14 \pm 3.34$ & $47.24 \pm 4.13$ & $>0.05$ \\
\hline \multirow{2}{*}{$\mathrm{R}-\mathrm{CT}(\mathrm{mm})$} & $M$ & $82.47 \pm 11.44$ & $68.51 \pm 6.31$ & $<0.05$ \\
\hline & $w$ & $73.57 \pm 9.83$ & $68.76 \pm 7.39$ & $<0.05$ \\
\hline \multirow{2}{*}{ L - CT (mm) } & $M$ & $83.50 \pm 11.19$ & $75.81 \pm 4.72$ & $<0.05$ \\
\hline & $w$ & $73.42 \pm 10.63$ & $68.51 \pm 4.38$ & $<0.05$ \\
\hline
\end{tabular}

Notes: ATD - angle atd; CTD - angle ctd; ATB - angle atb; BTC - angle btc; DAT - angle dat; AD - length of line ad; CT - length of line ct.

significantly lower than that of practically healthy women (see Table 3). There was no difference between the sick and healthy men according to these indicators (see Table 3).

\section{Discussion}

The data obtained by us allowed to reveal a combination of certain quantitative dermatological features characteristic of patients with ichthyosis and to demonstrate gender peculiarities.

For dermatoglyphics of men suffering from ichthyosis, quantitative signs are low intensity of the comb formation of the $I$ and $V$ fingers of the right hand, high values of the hand angles ctd on both hands and the angle atb on the left hand,
Table 3. Quantitative indices of palmar dermatoglyphics in men and women with icthiosis (the value of comb accounts and the Cummins index) (absolute units) $(\mathrm{M} \pm \sigma)$.

\begin{tabular}{|c|c|c|c|c|}
\hline \multirow{2}{*}{ Indicator } & Sex & $\begin{array}{c}\text { Practically } \\
\text { healthy (n=58 in } \\
\text { men) (n=78 in } \\
\text { women) }\end{array}$ & $\begin{array}{c}\text { Patients with } \\
\text { ichthyosis }(\mathrm{n}=24 \\
\text { in men) }(\mathrm{n}=25 \text { in } \\
\text { women) }\end{array}$ & $\mathrm{p}$ \\
\hline \multirow{2}{*}{$\mathrm{R}-\mathrm{AB}$} & $\mathrm{M}$ & $39.07 \pm 5.72$ & $37.49 \pm 6.18$ & $>0.05$ \\
\cline { 2 - 5 } & $\mathrm{W}$ & $39.35 \pm 4.89$ & $36.03 \pm 6.32$ & $<0.05$ \\
\hline \multirow{2}{*}{ L - AB } & $\mathrm{M}$ & $40.12 \pm 5.18$ & $37.88 \pm 7.25$ & $>0.05$ \\
\cline { 2 - 5 } & $\mathrm{W}$ & $40.46 \pm 6.05$ & $37.79 \pm 6.11$ & $<0.05$ \\
\hline \multirow{2}{*}{$\mathrm{R}-\mathrm{BC}$} & $\mathrm{M}$ & $26.41 \pm 6.08$ & $25.93 \pm 5.72$ & $>0.05$ \\
\cline { 2 - 5 } & $\mathrm{W}$ & $27.17 \pm 5.68$ & $24.24 \pm 5.96$ & $<0.05$ \\
\hline \multirow{2}{*}{$\mathrm{L}-\mathrm{BC}$} & $\mathrm{M}$ & $25.63 \pm 5.65$ & $25.78 \pm 5.97$ & $>0.05$ \\
\cline { 2 - 5 } & $\mathrm{W}$ & $26.71 \pm 6.28$ & $24.29 \pm 6.23$ & $>0.05$ \\
\hline \multirow{2}{*}{$\mathrm{R}-\mathrm{CD}$} & $\mathrm{M}$ & $37.20 \pm 7.04$ & $37.13 \pm 7.81$ & $>0.05$ \\
\cline { 2 - 5 } & $\mathrm{W}$ & $36.65 \pm 6.69$ & $36.93 \pm 7.25$ & $>0.05$ \\
\hline \multirow{2}{*}{$\mathrm{L}-\mathrm{CD}$} & $\mathrm{M}$ & $36.77 \pm 4.89$ & $37.09 \pm 5.69$ & $>0.05$ \\
\cline { 2 - 5 } & $\mathrm{W}$ & $35.63 \pm 7.62$ & $34.58 \pm 6.97$ & $<0.05$ \\
\hline \multirow{2}{*}{$\mathrm{R}-$ I } & $\mathrm{M}$ & $9.642 \pm 1.841$ & $7.751 \pm 3.224$ & $<0.05$ \\
\cline { 2 - 5 } & $\mathrm{W}$ & $9.024 \pm 1.923$ & $8.511 \pm 3.429$ & $>0.05$ \\
\hline \multirow{2}{*}{$\mathrm{L}-$ I } & $\mathrm{M}$ & $8.250 \pm 1.766$ & $7.883 \pm 3.118$ & $>0.05$ \\
\cline { 2 - 5 } & $\mathrm{W}$ & $8.324 \pm 2.119$ & $8.445 \pm 2.346$ & $>0.05$ \\
\hline
\end{tabular}

Notes: AB - comb account between the palm triradius a and b; BC - comb account between the palm triradius $b$ and $c ; C D$ - comb account between the palm triradius $c$ and $d ; I-$ index value of the main palmar lines (Cummins index).

as well as the small values of the Cummins index of the right hand and the segment c-t in comparison with practically healthy men.

The dermatoglyphic picture of women with ichthyosis is somewhat different from that of men. For them, the low intensity of the comb formation of the right IV finger, the low values of the comb accounts a-b of both hands, the b-c right and the c-d left hands, and, like men, the small values of the segment c-t, as compared to the practically healthy women, are characteristic.

It should be noted that the common feature for both sexes was a shorter distance between the palmar triads of $\mathrm{c}$ and $\mathrm{t}$ than in healthy ones, which is obviously due to the higher localization of triradius $c$ and $t$, as well as low finger intensity of comb formation.

Clinical practice and a number of scientific studies of 7080 years confirms that the most frequently vulgar ichthyosis is associated with atopy: atopic dermatitis, bronchial asthma, vasomotor rhinitis, and also with allergic skin diseases, immunodeficiency states, and functional endocrine disorder [18].

Dermatoglyphic picture of patients with atopic dermatitis, according to Gara A. V. and co-authors [7], is characterized by the simplicity of finger patterns with predominance of arches and random patterns, the saturation of the palm pattern, in this connection, there are additional axial triradius, 


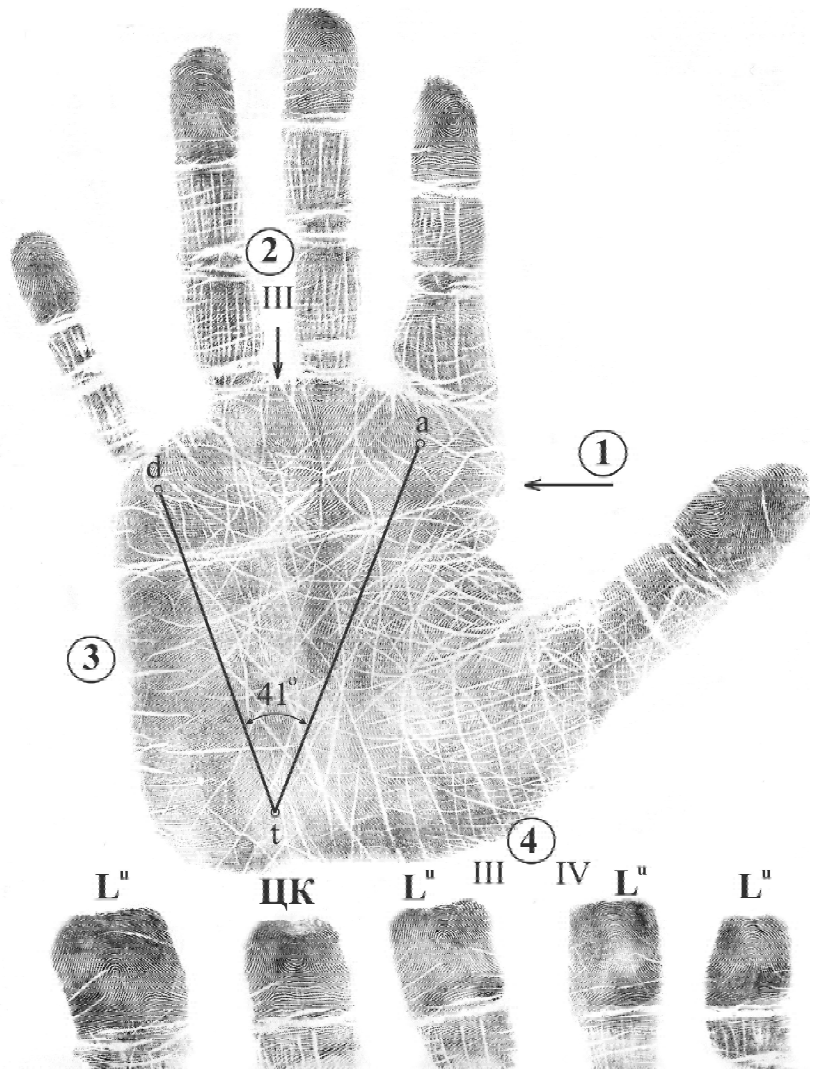

$\mathbf{L}$

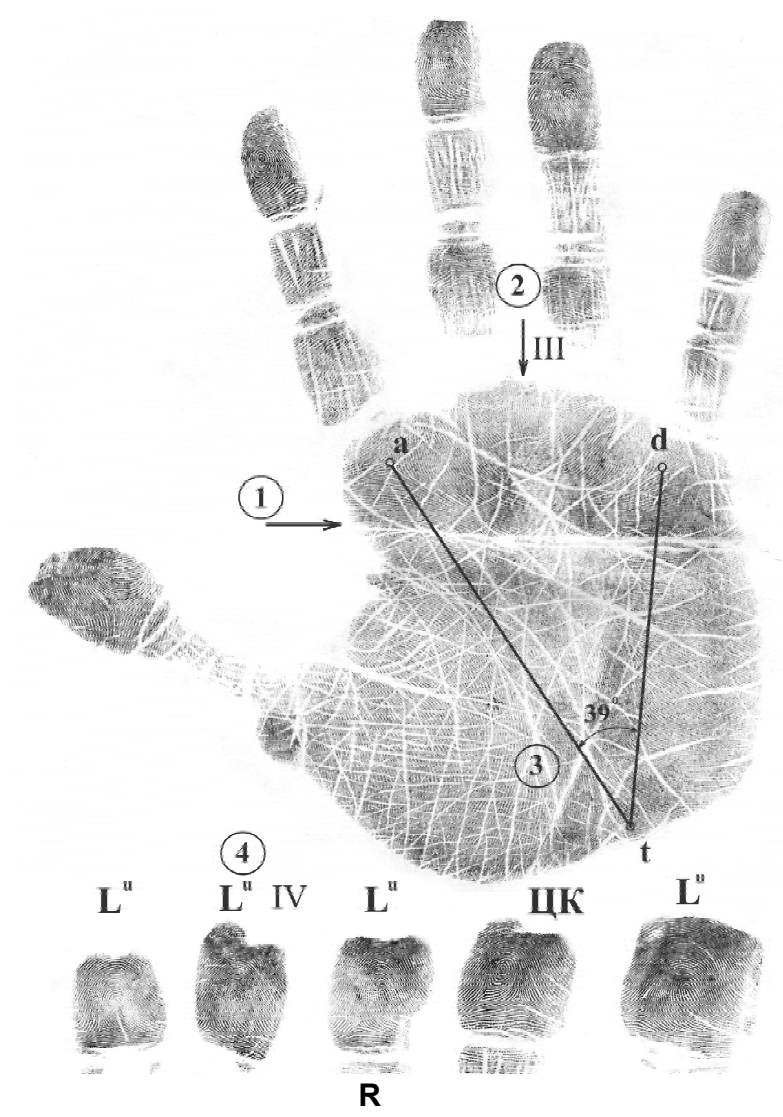

Fig. 3. Fingerprints of a patient with congenital lamellar ichthyosis [5]. L - left hand, $R$ - right hand; 1 - single 4-finger flexural fold, 2 - a pattern in the III interdigital gap, 3 - carpal angle atd; 4 - ulnar loop, complicated by an internal pattern on the third finger of the left hand and on the IV finger of the right hand.

and the angles get higher values in compared to healthy individuals, there is disharmony in saturation with papillary fingers (low comb count) and palms (high values of comb accounts).

In patients with bronchial asthma, there is an imbalance between the level of complexity of patterns and the value of the total comb account, as well as the low values of the Cummins index: in boys on both hands, and in girls on the right hand [25].

Patients with seasonal and year-round allergic rhinitis of urban adolescents were observed: in patients with seasonal rhinitis - a decrease in the length of the line c- $t$; in patients with year-round rhinitis - a decrease in the magnitude of the angle atb, an increase in the angles btc and dat, an increase in the interdigital comb account b-c, a decrease in the value of the Cummins index; the percentage of localization of palmar triradius in the carpal zone (decrease in patients with rhinitis) and in the zone of $t$ (increase in patients with rhinitis) [2]

Dmitrenko S. V. and Kolyadenko V. G. [4] revealed certain dermatological features of widespread psoriasis: smaller than the population values of the palm angles atd in the left hand in men and ctd on the right and atb at left hands in women, combined with the presence of patterns in the III interdigital gap between of both hands, and in IV of the right hand in men, as well as in the IV interdigital space between the left hand in women.

It should be recalled that in the previous study, when considering the qualitative signs of dermatoglyphics of patients with congenital ichthyosis of lamellar form, we obtained quite interesting results. The revealed complex of peculiarities of dermatoglyphics includes the monomorphism of established signs on both hands: the presence of a single 4-finger flexural fold, a pattern in the III interdigital gap, a low localization of the carpal angle atd and the presence of an ulnar loop, complicated by the internal pattern on the third finger of the left and IV finger of the right hand [5] (Fig. 3). It should be noted that the fourfinger flexural fold in ichthyosis was observed in $22.0 \%$ of cases, unlike the healthy population, where it occurs in $5.0 \%$ on the one palm and much less in both hands. The presence of this fold is considered to be one of the signs of genetic diseases or genetic chromosomal abnormalities, including Down syndrome (21st chromosome), Klinefelter syndrome, Patau syndrome (trisomy 13), and others. So, in the Down's disease, there is a distal shift of the axial triradius, a transverse 4-finger fold palm and dominate of arc on fingers; if Edwards syndrome (trisomy in the 16th18th pairs of chromosomes) - one can find arches on all fingers, as well as interdigital palm patterns in the IV field 
[28].

Thus, it is evident that certain revealed features of dermatoglyphics in patients with ichthyosis are part of the dermatotypes in diseases of other nosologies as monogenic and multifactorial nature.

Summing up the results of dermatoglyphic study of patients with ichthyosis, it should be noted, that we have fixed a certain complex of dermatological features, which allows to establish the genetic determinism of manifestations of ichthyosis. However, due to the high genetic heterogeneity of the disease, this effect was not equally detected in different patients, indicating the need for strict formation of the studied groups of patients, taking into account forms of ichthyosis.

\section{References}

[1] Abramova, T. F. (2003). Finger dermatoglyphics and physical abilities. (Ph. D. Biol. Sciences). Moscow. Retrieved from http://www.dslib.net/antropologia/palcevaja-dermatoglifika-ifizicheskie-sposobnosti.html

[2] Antonets, T. I. (2004). Anthropogenetic criteria for the development of allergic rhinitis in adolescents in the Podillya region of Ukraine. (Disserted for Candidate of Medical Sciences). Vinnytsya: Vinnytsia National Medical University.

[3] Cummins, H., \& Midlo, Ch. (1961). Finger Prints, Palms and Soles. An Introduction to Dermatoglyphics. Philadelphia. Retrieved from https://www.worldcat.org/title/finger-printspalms-and-soles-an-introduction-to-dermatoglyphics/oclc/ 355677

[4] Dmitrenko, S. V., \& Kolyadenko, V. G. (2006). Some anthropogenetic aspects of psoriasis. Ukrainian Journal of Dermatology, Venereology, Cosmetology, 3, 9-10. Retrieved from http://www.vitapol.com.ua/user_files/pdfs/uzdvk/ 975343944391391_27092009224008.pdf

[5] Dmytrenko, S. V., Klimas, L. A., \& Kaminskaya, N. A. (2012). Illustration of congenital ichthyosis by dermatoglyphics. Scientific and practical journal Archives of clinical and experimental medicine, 21 (2), 143-145.

[6] Gonemo, A., Sjoden, P. O., Johansson, E., Vahlquist, A., \& Lindberg, M. (2004). Health-related quality of life among patients with ichthyosis. Eur. J. Dermatol., 14 (1), 61-66. PMID: 14965800

[7] Gara, A. V., Klimas, L. A., \& Kaminska, N. A. (2013). Addition of standards for the diagnosis of atopic dermatitis with dermatoglyphic markers. The materials of the VII international congress of the international anthropology. Vinnitsa.

[8] Gara, A. V., Mateshuk Vatseba, L. R., Klimas, L. A., \& Ocheretna, O. L. (2012). Clinically significant variants of digital dermatoglyphics in girls suffering from atopic dermatitis. Reports of Vinnytsia National Medical University, 1 (16), 43-49.

[9] Govta, M. V. (2010). Dermatological Figures of the Population of the Ecological Crisis Territories. In Problems of ecology and nature protection of technogenic region. Donetsk: DonNU, 1 (10), 33-37.

[10] Gunas, I. V., Antonets, T. I., Sergeta, I. V., \& Klimas, L. A. (2004). Prediction of the risk of allergic rentits depending on the features of dermatoglyphics and some erythrocytic antigens of blood antigens in urban adolescents of different sexes by stepwise discriminatory analysis. Biomedical and Biosocial anthropology, 2, 134-138.

[11] Gunas, I. V., Protsyuk, T. L., Klimas, L. A., Kaminska, N. A., \&

\section{Conclusions}

1. The complex of dermatoglyphic features for ichthyosis according to the quantitative indicators includes: low intensity of the comb formation of the I and $\mathrm{V}$ hand fingers, high values of the angles of the ctd on both hands and the angle atb on the left hand, and also the small values of the Cummins index of the right hand and the c-t segment in comparison with men with ichthyosis.

2. The dermatoglyphic picture in women with ichthyosis is characterized by a low intensity of comb formation of the right IV hand finger, the low values of the comb accounts a$b$ of both hands, b-c of the right and c-d of the left hand, and also - small values of the segment c-t compared with the practically healthy women.

Shapoval, O. M. (2007). Forecasting of bronchial asthma in urban children of Podilsky region with the help of indicators of dermatoglyphics. Reports of Morphology, 13 (1), 149-152. Retrieved from https://dspace.vnmu.edu.ua/123456789/2438.

[12] Guseva, I. S., \& Sorokina, T. T. (1998). Dermatoglyphics as a constitutional marker for multifactorial pathology. Anthropology issues, 89, 99-111.

[13] Karlova, T. A., \& Gubareva, L. I. (2004). Dermatoglyphic markers of cerebrastenic syndrome. In Problems of rhythms in natural science, Materials of the Second International Symposium. Moscow: Publishing House RUFP.

[14] Klimas, L. A., \& Dmitrenko, S. V. (2008). Finger dermatoglyphics in various forms of psoriasis. World of Medicine and Biology, 1, 59-64.

[15] Klimas, L. A., Kostenko, M. P., Kaminska, N. A., Proligina, O. V., Vovchuk, O. M., Olkhova, I. V., \& Bashinska, O. I. (2009). Receiving and processing of dermatological fingerprints: complexity and interpretation. Reports of the National Medical University, 13 (2), 433-438.

[16] Klimas, L. A., Vovchuk, O. M., Shevchuk, Yu. G., \& Tiholaz, V. O. (2009). Cross-system connections: respiratory system - a system of dermatoglyphics. Herald Morphology, 15, 2, 457463.

[17] Klimas, L. A., Zhmurik, V. V., Kukhar, I. D., Boreiko, T. I., Kaminska, N. A., \& Sivak, A. V. (2008). Marker possibilities of dermatoglyphic signs in diabetes mellitus. In Problems of modern human morphology, Proceedings of the international conference dedicated to the 75th anniversary of the birth of Corresponding Member of the Russian Academy of Medical Sciences, prof. B.A. Nikityuk. Moscow. Retrieved from https:/ /revolution.allbest.ru/medicine/00586678_1.html.

[18] Lyashenko, N. V., \& Zagrtdinova, R. M. (Ed.) (2017). Genodermatosis: study guide. Izhevsk: Izhevsk State Medical Academy.

[19] Marvina, L. N. (2001). Hormonal regulation of calcium homeostasis in the process of keratinization of the epidermis. (Dis. Cand. Biol. Sciences). Yekaterinburg. Retrieved from http://www.dissercat.com/content/gormonalnayaregulyatsiya-gomeostaza-kaltsiya-v-protsesse-keratinizatsiiepidermisa.

[20] Mazur, E. S., \& Zvyagin, V. N. (Eds.) (2014). Dermatoglyphics in personality research: forensic and forensic aspects. Tomsk: Publishing House of Tomsk State University. Retrieved from http://vital.lib.tsu.ru/vital/access/manager/Repository/ vtls:000507639. 
[21] Negasheva, M. A. (2008). The morphological constitution of a man in the youthful period of ontogenesis: integral aspects (Dis. Doctor of Biological Sciences). Moscow: Moscow State University Lomonosov. Retrieved from http:// www.dissercat.com/content/morfologicheskayakonstitutsiya-cheloveka-v-yunosheskom-periodeontogeneza-integralnye-aspek.

[22] Nikityuk, B. A. (2000). Integration of knowledge in the sciences of man (modern integrative anthropology). Moscow: Sport Academ Press. ISBN: 5-8134-0025-7.

[23] Oyama, M., Satoh, M., Iwatsuki, K., \& Kaneko, F. (2000). Novel point mutations in the steroid sulfatase gene in patients with X-linked ichthyosis: transfection analysis using the mutated genes. J. Invest. Dermatol., 114 (6), 1195-1199. https://doi.org/ 10.1046/j.1523-1747.2000.00004.x.

[24] Pour-Jafari, H., Farhud, D. D., Yazdani, A., \& Hashemzadeh Chaleshtori, M. (2003). Dermatoglyphics (fingerprint) in patients with eczema, psoriasis and alopecia areata. Skin. Res. Technol., 9 (3), 240-244. Retrieved from https:// www.ncbi.nlm.nih.gov/pubmed/12877685.

[25] Protsyuk, T. L. (2008). Prediction and peculiarities of the course of bronchial asthma in urban and rural schoolchildren of the Podilsky region of Ukraine. (Doctor of Medical Sciences). Kharkiv: Kharkiv National Medical University.

[26] Protsyuk, T. L. (2009). Prognostic and prescriptive criteria for the emergence of bronchial asthma in children. Child health, 5(20), 60-65.

[27] Rodriguez-Pazos, L., Ginarte, M., Vega, A., \& Toribio, J. (2013).
Autosomal recessive congenital ichthyosis. Actas Dermosifiliogr., 104(4), 270-284. doi: 10.1016/ j.adengl.2011.11.021.

[28] Schaumann, B., \& Alter, M. (1976). Dermatoglyphics in Medical Disorders. New York: Springer-Verlag. Retrieved from https:/ /www.springer.com/gp/book/9783642516221.

[29] Sergeta, I. V., Gara, A. V., \& Klimas, L. A. (2011). Clinically significant variants of digital dermatoglyphics in boys suffering from atopic dermatitis. Biomedical and biosocial anthropology, 17, 57-63.

[30] Shinkaruk-Dikovitskaya, M., \& Borisenko, A. (2015). Local administrative-territorial specificity of dermatoglyphics of men of Ukraine affected by caries of average intensity level. Current Issues in Pharmacy and Medical Sciences, 28(1), 51-54. doi: https://doi.org/10.1515/cipms-2015-0043

[31] Solonichenko, V. G., Bogdanov, N. N., Ostreiko, T. Ya., \& Malyshev, Yu. I. (1997). Dermatoglyphic pattern in Tourette syndrome. Human physiology, 23 (1), 113-117. Retrieved from http://www.rusmedserv.com/genetics/dermatol/user/sintur/.

[32] Tegako, L. I. (2008). Scientific palmistry. Moscow: Exmo.

[33] Vasilenko, Yu. A. (2005). Parallelism of changes in dermatoglyphics, endocrine and mental status in the population of the child population living in areas with a high anthropogenic load. (Dis. Cand. Biol. Sciences. Stavropol: Stavropol State University.

[34] Wertelecki, W., \& Plato, Ch. C. (Eds.) (1980). Dermatoglyphics - 50 Years Later. New York: Alan R. Liss. Retrieved from https://trove.nla.gov.au/version/10736068.

\section{ОСОБЛИВОСТІ КІЛЬКІСНИХ ПОКАЗНИКІВ ПАЛЬЦЕВОЇ І ДОЛОННОЇ ДЕРМАТОГЛІФІКИ У ХВОРИХ НА ІХТІОЗ ЧОЛОВІКІВ І ЖІНОК}

Дмитренко С. В., Клімас Л. А., Кушнір В. А., Серебреннікова О. А., Сергета І. В.

Гетерогенність за типами успадкування генодерматозів з групи іхтіозу, що включають в себе фрактично всі можливі варіанти, є підставою для застосування одного з генетичних методів вивчення людини - методу дерматогліфріки. Мета дослідження - встановити особливості кількісних показників пальцевої і долонної дерматогліфріки у хворих на іхтіоз чоловіків і жінок. Дерматогліфічне обстеження проведено у 49 хворих на іхтіоз і у 136 дерматологічно здорових осіб. Вибірка хворих проводилась випадковим способом. У всіх осіб була отримана інформована згода на проведення спостережень. Відбитки папілярної шкіри пальців і долонь отримані шляхом сканування відбитків на папері сканером Futronic's FS8 USB2.0 Fingerprint Scanner з використанням програми ftrScanApiEx.exe, з подальшим перенесенням даних на персональний комп'ютер. Обробку дерматогліфів проводили за методикою H. Cummins i Ch. Midlo (1961). Визначали кількісні показники як пальцевої, так $і$ долонної дерматогліфіки. Обчислення отриманих результатів проводили в ліцензійному пакеті програм "Statistica 5.5". Визначали середні вибіркових значень (M) та дисперсії (б) у групах обстежених осіб. За допомогою U-критерію Мана-Уітні визначали вірогідність відмінностей отриманих результатів для окремих груп. Виявлено певний комплекс кількісних ознак долонної дерматогліфіки, характерний для чоловіків, хворих на іхтіоз, що включає показники пальцевої інтенсивності гребенеутворення, значення довжини відрізка c-t, значення долонних кутів та індексу Каммінса. У жінок, хворих на іхтіоз, такий комплекс включає, як і в чоловіків, показники пальцевої інтенсивності гребенеутворення та значення довжини відрізка $c$ - $t$, окрім яких - ще й значення долонних гребінцевих рахунків. Враховуючи специфічну для ламелярної форми іхтіозу дерматогліфічну картину (мономорфність встановлених ознак на обох кистях: наявність єдиної 4-пальцевої згинальної складки, візерунка в III міжпальцевому проміжку, низької локалізації карпального кута аtd і наявність ульнарної петлі, ускладненої внутрішнім візерунком на III пальці лівої і на IV пальці правої кистей), автори прийшли до висновку, що дослідження іхтіозу потрібно проводити обов'язково для кожної форми іхтіозу окремо, що значно підвищить роздільну здатність методу дерматогліфіки.

Ключові слова: іхтіоз, ламелярна фрорма іхтіозу, дерматогліфіка, чоловіки, жінки.

\section{ОСОБЕННОСТИ КОЛИЧЕСТВЕННЫХ ПОКАЗАТЕЛЕЙ ПАЛЬЦЕВОЙ И ЛАДОННОЙ ДЕРМАТОГЛИФИКИ У БОЛЬНЫХ ИХТИОЗОМ МУЖЧИН И ЖЕНЩИН}

\section{Дмитренко С. В., Климас Л. А., Кушнир В. А., Серебренникова О. А., Сергета И. В.}

Гетерогенность по типам наследования генодерматозов из группы ихтиоза, включающих в себя практически все возможные варианты, является основанием для применения одного из генетических методов изучения человека - метода дерматоглифики. Цель исследования - установить особенности количественных показателей пальцевой и ладонной дерматоглифики у больных ихтиозом мужчин и женщин. Дерматоглифическое обследование проведено у 49 больных ихтиозом и в 136 дерматологически здоровых лиц. Выборка больных проводилась случайным образом. У всех лиц было получено информированное согласие на проведение наблюдений. Отпечатки папиллярной кожи пальцев и ладоней получены 
путем сканирования отпечатков на бумаге сканером Futronic's FS8 USB2.0 Fingerprint Scanner с использованием программы ftrScanApiEx.exe, с последующим переносом данных на персональный компьютер. Обработку дерматоглифоов проводили по методике H. Cummins u Ch. Midlo (1961). Определяли количественные показатели как пальцевой, так и ладонной дерматоглифики. Вычисления полученных результатов проводили в личензионном пакете программ "Statistica 5.5". Определяли средние выборочных значений (M) и дисперсии (б) в группах обследованных лиц. С помощью U-критерия МанаУитни определяли вероятность различий полученных результатов для отдельных групп. Выявлено определенный комплекс количественных признаков ладонной дерматоглифики, характерный для мужчин, больных ихтиозом, включая показатели пальцевой интенсивности гребнеобразования, значение длины отрезка c-t, значение ладонных углов и индекса Камминса. $У$ женщин, больных ихтиозом, такой комплекс включает, как и у мужчин, показатели пальцевой интенсивности гребнеобразования и значение длины отрезка c-t, кроме которых - еще и значение ладонных гребневых счетов. Учитывая специфическую для ламелярной фрормы ихтиоза дерматоглифической картины (мономорфрность установленных признаков на обоих кистях: наличие единой 4-пальцевой изгибной складки, узора в III межпальцевом промежутке, низкой локализации карпального угла atd и наличие ульнарной петли, осложненной внутренним узором на III пальце левой и на IV пальце правой кистей), авторы пришли к выводу, что исследования ихтиоза нужно проводить обязательно для каждой формы ихтиоза отдельно, что значительно повысит разрешающую способность метода дерматоглифики.

Ключевые слова: ихтиоз, ламеллярная форма ихтиоза, дерматоглифика, мужчины, женщины. 